\title{
Archipel
}

ARCHIPEL Études interdisciplinaires sur le monde insulindien

Hors-Série $n^{\circ} \mathbf{2}$ - Patani Through Foreign Eyes: Sixteenth And Seventeenth Centuries (Edited By Daniel Perret \& Jorge Santos Alves) | 2022

Patani Through Foreign Eyes: Sixteenth And

Seventeenth Centuries

\section{G. Glossary}

Daniel Perret and Jorge Santos Alves

\section{(2) OpenEdition \\ 1 Journals}

Electronic version

URL: https://journals.openedition.org/archipel/2831

DOI: $10.4000 /$ archipel.2831

ISSN: 2104-3655

Publisher

Association Archipel

\section{Printed version}

Date of publication: 28 February 2022

ISBN: 978-2-910513-88-7

ISSN: 0044-8613

Electronic reference

Daniel Perret and Jorge Santos Alves, "G. Glossary", Archipel [Online], Hors-Série n² - Patani Through Foreign Eyes: Sixteenth And Seventeenth Centuries (Edited By Daniel Perret \& Jorge Santos Alves) | 2022, Online since 28 February 2022, connection on 18 March 2022. URL: http:// journals.openedition.org/archipel/2831; DOI: https://doi.org/10.4000/archipel.2831 


\section{G. Glossary}

aguelæ: fragrant resin-infiltrated wood called aloeswood, agarwood, eaglewood, or gaharu in Malay. The tree species affected by this pathology belong to the genus Aquilaria, the chief source being A. malaccensis (Burkhill 1993: 198-206). The best aloeswood is called calambac by the Portuguese in the sixteenth century (Orta 2004: 370).

Álvares, Gonçalo: Portuguese sea officer that served the Estado da Índia as captain of Sofala, and as Captain-Major of the India fleet.

alvas: old Spanish word, here referring the young virgin women.

Amboin / Amboina / Amboyn: Ambon, today part of the Maluku Islands, Maluku Province in Indonesia. Well-known for its plantations of cloves, the island was occupied by the Portuguese soon after the conquest of Malacca. In 1605, the Portuguese were driven out by the Dutch who enjoyed the exclusive monopoly on clove trade in the archipelago from 1656. See Moluccos.

Andrigiery / Andrygiri / Andrigirij / Andrigiri / Andraguire: Indragiri. River arising in the Minangkabau highlands and polity of eastern Sumatra. Since the beginning of the seventeenth century at least, Indragiri was among the trade entrepots for the pepper cultivated in the hinterland and in the Minangkabau region.

arack: arak, alcoholic beverage made from various species of palm trees. arcabuseria: arcabuzeria, a volley of arcabuz shots.

Areca: A small genus of the Palmae family, common in tropical Asia. The chief of them is Areca catechu Linn., which gives the nut used as 
component of the betel quid.

Atchin / Achem: Aceh. A major sultanate at the northern tip of Sumatra.

Avaa: the kingdom of Ava, dominant over upper Burma (Myanmar) from 1364 to the mid-16th century.

Baçora: the Iraqui port-city of Basra.

baer / bhaer / bhaar: bahar. According to Pieter de Carpentier et al. (1626), in Patani a bahar weights six "Bantam bags" (see Bantamsche zacquen), that is approximately $180 \mathrm{~kg}$.

ballaia / ballee / balleye: corrupted form of the Malay balai. Unwalled or low-walled building where people meet.

Bandan: Banda. A ten-island archipelago presently in the Indonesian province of Maluku, well-known as the sole source of nutmeg and mace during the period under review here. The Portuguese began to visit the island soon after the conquest of Malacca in 1511. The VOC enjoyed a monopoly on these products from 1621. See Moluccos.

Bandar-malsin: Banjarmasin. Capital of the sultanate of the same name (or Banjar) in the present province of South Kalimantan (Indonesia), located in the southern part of Borneo. Banjarmasin began to grow pepper in ca. 1630.

Bandara, Bandora, Dato: a high-ranking official described as the "governor of Patani" in 1622. This position might have been equivalent to bendahara, a kind of "prime minister" in other kingdoms of Maritime Southeast Asia. Cf. chapter "Domestic Issues".

Bantam: Banten. Since 1524, a major kingdom in the western part of Java with its capital in Banten. Banten was a major pepper producer until about 1620. The VOC took control of this sultanate in 1682.

Bantamsche zacquen: Banten bag. A unit of weight generally used for pepper, equivalent to about $30 \mathrm{~kg}$.

barre: see baer.

bas: Small bronze ship cannon without carriage. Translated here as "fowler".

batian: could be a corrupted form of bachang (horse-mango = Mangifera foetida), a fruit almost disguting to Europeans, but relished by the natives (Crawfurd, vol. I, 1820: 425).

\section{Benjarmasingh: see Bandar-malsin.}

betel / bethel: in Southeast Asia, the betel quid is a combination of betel leaf (from Piper betle vine) together with areca nut (see areca above), lime and other additives.

bhaer / bhaar: see baer.

Bintão: Bintan. The port and sultanate in the Malay Peninsula, close to 
Malacca and the siege of the former sultans of Malacca, after the Portuguese conquest in 1511.

bisschop: refers here to the highest religious Muslim authority in Patani.

Bocht (van Patani): Name used by the Dutch in the seventeenth century for the coastal area between Ligor (present Nakhon Si Thammarat) and Patani.

Bongso: see Rahu.

Bordolongh / Burdelon: Phatthalung. Today one of the southern province of Thailand, between Nakhon Si Thammarat Province and Songkhla Province. One of the seaports along the southeastern coast of Peninsular Thailand, probably since the fourteenth century.

Borneo / Bornea: the sultanate of Brunei on the north coast of the island of Borneo.

brahala: corrupted form for the Malay berhala. Generic Malay term for all kinds of religious images. Idol.

Brandão, Luís: a Portuguese ship captain.

Burdelon: see Bordolongh.

calaluz: term used by some Portuguese writers for swift galleys with many oarsmen, such as were particularly prevalent in eastern Indonesia of the sixteenth century. It may be derived from Javanese kelulus (a 'threader', able to go through [lulus]).

calamba: see aguelæ. According to Pires at the beginning of the sixteenth century, calambac was the chief merchandise of Cāmpa (Pires, I, 1990: 113).

calynder: a type of cloth.

Cambaia: the Indian sultanate and port-city of Cambay, in Gujarat.

Cambodja / Camboja / Camboya: Cambodia.

camellos: camelo, short range piece of artillery, firing small iron balls.

cameloth: camlet, camblet. A fine and expensive cloth woven from Angora goat hair or mixtures of silk and hair or silk and wool (Farrington \& na Pombejra 2007, vol. II: 1396).

Camperhooft: Kamperhoofd. On a map of Amsterdam dated 1649, Kamper hooft is a bastion at the entrance of the city, located near Schrey horcks Toor (Blaeu 1649). Renamed Prins Hendrikkade since 1879.

camphar (Chinese): Chinese camphor. Product extracted from a tree (Cinnamomum camphora) belonging to the Lauraceae family found originally in southern Japan, mid-east China, present Taiwan, and present Vietnam. Camphor is formed in oil-cells, which occur in all parts of the tree. Young parts are distilled to produce an oil more or less rich 
in camphor (Burkill, vol. I, 1966: 553-555). By mid-sixteenth century, Garcia de Orta (2004: 137) observed that a quintal of Chinese camphor was worth a pound of Borneo camphor. The latter, as well as the Sumatra camphor, is produced by an other species (Dryobalanops sumatrensis).

Campher / Campor: Kampar. River arising in the Minangkabau highlands and polity of eastern Sumatra. Since the beginning of the seventeenth century at least, Kampar was among the trading entrepots for pepper cultivated in the hinterland and in the Minangkabau region.

Campon China: corrupted form of "Kampung Cina" in Malay. It refers to the Chinese quarter in a settlement.

canes: cães, portable small piece of artillery, spinning around a stable axe.

carauella: caravela, a Portuguese sailing ship, with two or three masts.

catti / catty: kati in Malay. a weight used in China, and introduced by the Chinese in Maritime Southeast Asia. Albeit not uniform (Hobson-Jobson 1994: 175), it seems to have been often equivalent to 600 grams. It was generally subdivided into taels.

Cauchinchina / Cauchin China: from late fifteenth century until early seventeenth century (including in the sources presented in this volume), this name referred to the Kingdom of Đại Việt. In the course of the seventeenth century, with the increasing knowledge about the kingdom, European sources began to distinguish the Red River region (Tonquin or Tonkin) from Cochinchina situated in southern Đại Việt (Aurousseau 1924: 566-567; Wheeler 2010: 164-165).

Celatão: The polity of Kelantan, on the northeast coast of the Malay Peninsula, south of Pattani, for which historical data are very fragmentary, and therefore very difficult to corroborate as regards the sixteenth and seventeenth centuries. Visited by a Zheng He mission in 1411/12, the local ruler sent an envoy to the Chinese court to offer a tribute (Wade 2004: 63). Still according to a Chinese source, remnants of "pirate bands" fled to Kelantan by the mid-sixteenth century (ibid.: 62). According to the Sejarah Melayu, at the time of Sultan Mahmud Syah of Melaka (14881511), the Kelantan Muslim ruler was Sultan Mansor Syah (Shellabear ed. 1994: 152) or Sultan Menawar Syah (Abdul Samad bin Ahmad ed. 1986: 203).

centul: sentul, also known locally as kecapi (Sandoricum koetjape (Burm. f.) Merr.). The tree, which grows from sea level to about 1,000 meters may be native to the Malay Peninsula, and produces two varieties of fruits (yellow and red). The pulp can be cooked and candied or made into marmalade (perhaps a component of the confitueren in Dutch sources).

Chattis: designation of a caste of traders in South India. It seems that from the seventeenth century onwards, the term was commonly used for any 
South Indian involved, in a way or another, in trade (Arasaratnam 1986: 213-214, 1995: 42).

Champá: a series of coastal kingdoms that united a complex cultural zone of highland, lowland and coastal peoples inhabiting what is now Central Vietnam.

Chiam / Chiammers: the kingdom of Siam / people from Siam.

Chinceo / Chinchéu: For the period under consideration here (16th c. 17th c.), Chincheo is used to refer to Yuegang (lit. "port of the Moon"), the harbour of Zhangzhou, and the surrounding areas, in the prefecture of the same name located in southern Fujian province. Contrary to some assertions, at the time, it cannot refer to Quanzhou, which since the fall of the Mongols had greatly declined (Salmon 2010: note 4 p. 88). In 1567, Yuegang, formerly a smuggling centre, has been designated as the only port where Sino-foreign maritime trade could take place. After the disruption of Fujian maritime foreign trade from ca. 1640 until ca. 1680, Fujian ceased to enjoy the monopoly of all Sino-foreign trade, and Xiamen (Amoy) was replacing Yuegang as the major port for foreign trade in Fujian (Pin-tsun Chang 2006: 23). In Portuguese/European sources of the sixteenth and early seventeenth centuries, Zhangzhou is always the right identification for the port of "Chinchéu", as one can see in the first Portuguese-Chinese dictionary, compiled in Zhaoquing and Macau by the Jesuits Michelle Ruggieri and Matteo Ricci (between 1583 and 1588), that cleary identifies (at fl. 161) “chincheo” as 漳州 (Zhangzhou). On this see Witek S.J. 2001.

Chodsie: probably a corrupted form of khoja. This term of Persian origin refers to several situations. Stricto sensu, khoja refers to an endogamous group in India converted to Islam, including Nizaris Ismailis, a number of Sunnis and Twelvers separated from the Ismaili community. In a larger meaning, khoja refers to all Indian Nizaris Ismailis. According to other interpretations, khoja was a title confered to eunuchs in India and to rich merchants in Persia. But this latter meaning seems to have been popular in Gujarat also. Thus, the title "Khwajah" appears regularly in the inscriptions on white marble tombstones from Cambay dating between the thirteenth and the fifteenth centuries. To add further meaning uncertainties, in fifteenth century Malacca, the Chinese Muslim community coming from Jiangxi, specialised in accompanying tributary missions sent by Malacca to China, included at least two khojas, Khoja Ali alias Xiao Mingju and Khoja Husain (Alves 2003: 173).

Coala Tauar: Kuala Tauar River: probably a river located in the present district of Nongchik, west of Pattani. The report of an expedition conducted by a team from the Cambridge University in 1899/1900 mentions a Kampung Tawar in the Nongchik area (Gibson-Hill et al. 1953:169).

Coala Tiua: Kuala Tiua River: probably a river to the west of the Kuala Tauar 
River. Perhaps the Khlaung (river) Tha Rua in the same Nongchik area (Gibson-Hill et al. 1953:169).

Cojacão: Khoja Hassan. An officer from the sultan of Malacca, sent as ambassador to Zhengde Emperor of the Ming dynasty.

compan / coupan / coupon: corrupted form of kupang in Malay. A monetary unit worth about nine stuivers at the turn of the seventeenth century in Patani. The kupang was still used by late nineteenth century in Kelantan (4 kupang = 1 amas)(Linehan 1934: 67). See stuyver.

confitueren: fruits, roots, herbs, flowers, saps and juices, prepared and cooked in sugar or honey. Eight types of confitueren were differentiated: liquid confitueren, compotes (kind of semi-liquid paste made of the pulp of fruits or flowers - including ginger compote brought from the East Indies via Holland), jellies, pastes (thick compotes, including ginger pastes brought from the East Indies via Holland), dry confitueren, preserved confitueren, candies, and sugar-coated confitueren (Savary 1748, vol. 2: 573-575). See also centul.

corge: a mercantile term common in India during the sixteenth and seventeenth centuries to describe a bale or lot of 20 pieces of cloth.

coupan: see compan.

craecke: carrack (Portuguese carraca). Large and generally lightly-armed Portuguese trading ship used mainly in the sixteenth and seventeenth centuries.

cris / crits / crys: corrupted form of the Malay keris. Short, straight, doubleedged dagger in the Indonesian archipelago and Malay Peninsula.

cromsteyen: cromsteven. A small warship used in the sixteenth and seventeenth centuries, whose stem is concave.

cruzado: Portuguese gold coin weighing roughly 30 grams, worth 360 réis.

culebrina: colubrina, long and small caliber piece of artillery, firing cast iron balls weighing 16 to 18 pounds.

Cunha, Aires da: a Portuguese military officer, that served in the Estado da Índia as Captain of Kollam (in Kerala), and as Sea-Captain of Malacca, during the 1510 and 1520 's.

Cunha, Vasco da: a Portuguese nobleman (fidalgo), that served as soldier and administrator of the Estado da Índia.

damast: damask. Chinese silk or silk mixture fabric with elaborate designs.

Dato / Datoe / Dator: Dato'. Term of distinction for non-royal chiefs, during the period of interest here.

Dato Besaer / Datoe Bessar / Dato Basar: cf. chapter "domestic issues".

Díaz, Pero: a Spanish sailor and trader, from Monterrey, Orense. 
distar: corrupted form of the Malay destar. Headcloth.

Dugga Ragni: cf. chapter "domestic issues".

Empau / Empan: Chinese merchant from Patani, who went to Holland and was baptised there. Worked for the VOC in its dealings with China at the beginning of the seventeenth century. Died in the Moluccas around 1613 (cf. Blussé 1977).

Ericatin, Eriacatim, Fracaria: problably Arya Kadih (?), a Javanese seacaptain and corsair.

esfera: espera, a short-range piece of artillery, distinctive for having a sphere (representing the world) casted in its barrel.

fermelioen: vermilion. Synthetic red pigment obtained through many recipes, including uniting mercury and sulphur. The Chinese may have invented the process early in the Christian era. In the sixteenth and seventeenth century, vermilion was commonly used in Europe by painters (Gettens, Feller \& Chase 1972).

Ferreira, João: Portuguese soldier, apparently a veteran in Asia. One can find him in Malacca and in the early 1530's, being said to be already fluent in Malay.

folie: mace. The crimson net-like mantle, which envelops the hard outer shell of the nutmeg, when separated and dried, constitutes the mace of commerce (Hobson-Jobson 1994: 529).

Fonseca, António Pinto da: Portuguese veteran of Asia, Captain-General of Malacca for almost two decades (1616-1635). His tombstone can still be seen in St. Paul's Church (former Igreja de Nossa Senhora do Monte), at Malacca.

fusta: foist, a long-oared boat with a lateen sail.

galeão: a Portuguese ship with four masts, heavily armed with artillery.

galeye: a type of rowed vessel.

Grece: Gresik. A port-city and polity on the north coast of East Java. With its destruction in 1622, the kingdom of Mataram took control of almost the whole north coast of Java.

Guzaratta / Gusarat: Gujarat in Western India. The sultanate of Gujarat remained independent until 1572/73, when it was annexed by the Mughal Empire under Akbar-the-Great. Surat became the main port of the empire, supplanting Cambay. In 1630, a serious economic crisis in Gujarat led to the shifting of the cotton culture and industries towards Coromandel.

Hascan: the altered name of an individual. The correct spelling is probably "Hasan".

hasta: the length of the forearm from elbow to finger-tip. 
Iambi / Iamby / Jamby: Jambi. Situated on the east coast of Sumatra, this polity was an important producer of pepper. Ruled by a Palembang princess between 1630 and ca. 1665 .

Iangoma: Jangomá is the Burmese rendering of Chiang Mai, the capital of the kingdom of Lan Na. It may also refer to the whole kingdom (Grabowsky 2010: 209).

Iappon / Iappan: Japan.

Idoch, Dato: cf. chapter "domestic issues".

Ihoor / Iehor / Ior: see Jhoor.

iurebassa / iuarabassa: see jurubassa.

jacht: light boat very similar to the pinas with a shallow draft.

jalia: small and light vessel, smaller than the sandeel, with fifteen rows of oars on each side, widely used in some coastal areas of Southeast Asia.

Jhoor / Joor: Johor. A river in the southern part of the Malay Peninsula and a sultanate with its capital in various places along this river from ca. 1535 until the early eighteenth century.

jonck(e): junk. In the sources presented here, it is an ubiquitous word referring not only to a large Chinese ship but also to Southeast Asian or hybrid trading vessels (Manguin 1984).

Jortan: Jaratan. Town on the north coast of Java, close to Gresik. Controlled by Mataram from 1622 onwards.

jurubassa: corrupted form of the Malay juru bahasa, meaning literally "expert in language", here interpreter.

jurupangos: jerubung, that is a midship awning of a Malay vessel, comparable in size with a small Portuguese caravell.

Jusarte, Martim Afonso de Melo: a Portuguese military officer, that served the Estado da Índia as Captain of Hormuz, and as captain of war ships in the Straits of Malacca in the 1520s.

Keda: Kedah. A sultanate on the northwest coast of the Malay Peninsula. Its port, notably frequented by South Asian traders, supplied mostly pepper, tin and elephants. After the destruction of its pepper plantations in 1618, the sultanate fell under the authority of Aceh until ca. 1640.

$\operatorname{kerck}(\mathbf{e})$ : in the seventeenth century Dutch sources, a general term to describe a place of worship. In the sources presented in this volume, it refers to mosques, pagodas, or Christian churches.

Lacsemana / Laxmanna / Laquexemena, Dato: corrupted word for laksamana in Malay language. In Patani, Dato Laksamana is the title of the syahbandar at the beginning of the seventeenth century. Usually at the time, in the sultanates of Maritime Southeast Asia laksamana refers to the 
head of the naval forces.

lanchara: lancaran, a Malay fast war vessel propelled by oars and a sail.

lanciat: corrupted form for the Malay langsat. A yellow-white fruit (Lansium domesticum).

lapis besar: this Malay expression is a corruption of the Latin lapis bezoar (Orientalis) to describe hard concretions found in the bodies of animals, to which antidotal virtues were ascribed. Coincidentally, the meaning of lapis is "layer" in Malay, and these concretions usually show fine concentric layers. "Besar" is a corruption of the Persian "päzhar" (pellens venenum), recalling the fact that Persia, and especially Khorasan, was reputed as the best place for bezoar (See Lemery 1727: 124; Hobson-Jobson 1994: 9091). Pāzhar itself originates from the pāzhar goat, living in the mountains of Turkey, Iran and Pakistan. According to several Portuguese and other European sources, bezoar was also found in porcupines in Pahang, Johor and Siak. The therapeutical value of the bezoar for many kinds of pains was still fashionable in the middle of the eighteenth century (Savary, vol. 1, 1748: 435-436). On the several types, markets and falsifications of the bezoar, see Alves (2003b).

last: A unit of volume and later weight. For the VOC: 1 last $=20$ piculs $\approx 1250$ $\mathrm{kg}$ (in the seventeenth century). Cf. VOC Glossarium (http://resources. huygens. knaw.nl/vocglossarium/vocoutp).

Ligor/ Lugor/ Lygoor: present Nakhon Si Thammarat on the east coast of Peninsular Thailand.

Lima, Francisco de: a Portuguese nobleman (fidalgo), that served the Estado da Índia in several areas of the India Ocean, namely in the Straits of Malacca in the 1530s.

limon gibol: fruit of the Citrus spp. Or could be the jambu bol, a guava variety, rose apple (Eugenia malaccensis).

Lobo, Tomé: a Portuguese veteran of Asia. He arrived in India in 1518, and we find him as factor (feitor) of Hormuz in 1522. By the end of this year, he shifted to Malacca where he was serving as soldier. In 1539/1540 he was resident factor of the captains of Malacca in Pahang. In 1548 he was still alive in Goa.

Macalser / Maccasar: Makassar. The town had a population of several thousands at the end of the sixteenth century and developped, at least since the beginning of the following century, as a transit point for Mollucas spices in exchange for rice and Indian cloths. With the progressive implementation of a monopoly on Mollucas spices by the VOC in the second quarter of the seventeenth century, followed by the conquest of Malacca in 1641, Makassar became a main alternative market for the 
opponents of the Company until its conquest in 1667. This takeover put an end to the smuggling of Mollucas spices and sanctionned the absolute monopoly of the VOC on these products. The Company took also this opportunity to seize the monopoly on the trade in Indian and Persian cloths in Makassar, preventing the other trading companies, as well as South Asian and Maritime Southeast Asian traders to come to do business freely.

maes: mas. Patani currency unit equivalent to $2 / 3$ of a real-of-eight (see rial van acht) at the very beginning of the seventeenth century. This history of monetary issuance by the sultanate of Patani is far from clear. Chance finds of gold coins bearing the effigy of a deer (kijang) and Arabic inscriptions, on or near the site of the old capital (Ban Kruse / Kerisik), have been reported since the end of the nineteenth century (cf. "introduction" in this volume). Thus we learn from one of the rare contemporaneous account that in 1645, a Dutch ship left Kedah with, among others, 400 Patani mas (DR 07/1645).

Maha Indeva: cf. chapter "domestic issues".

Maha Raia: cf. chapter "domestic issues".

maldemadiu: weighing officer? Malder was a measure of volume for grain in Germany (Savary, vol. 3, 1741, p. 237).

malim: mate or navigating officer.

Mallucos: see Moluccos.

Malusian: Malay.

mamide: it seems that no such currency has ever been issued in Cambodia at the time. Mamide may be a corruption of the Persian silver coin mamüdi (or mahmüdi), known to have been in circulation in the East Indies. The Safavid ruler 'Abbās I (1588-1629) emitted the silver 'abbāsī, with the mamūdi being valued at one half 'abbāsī (Frey 1916: 141; http://www. iranicaonline.org/articles/coins-and-coinage; see also Savary, vol. 3, 1741, p. 240).

mamplan: corrupted form of the Malay mampelam $=$ mempelam, that is mango (Mangifera indica).

Manchaja: cf. chapter "domestic issues".

Mardijcker: free "unmixed" Asian in the Dutch East Indies, who belonged to the category of burgher (burger). This word, derived from a Sanskrit term at the origin of the word merdeka (free, independent) in Indonesian, was commonly used from the 1630s. Spurred on by the VOC, this group was officially established by ordinance in 1643 (Fox 1983, p. 253). Among these Mardijkers, the Dutch sources differentiated the "Blacks" (swarte), originally from South Asia, and the "Malays" (maleytse). However, most 
of them were liberated slaves from Coromandel, Malabar and Ceylon, and were baptised before to be freed. Another common feature was the use of a Portuguese-based Creole language.

Martavão: Martaban, also Muttama (in modern Burmese), was an important port-city of Lower Burma between the fourteenth and the late sixteenth century when it was eclipsed by Syriam.

Mello, Simão de: Portuguese nobleman (fidalgo), Captain of Malacca between 1545 and 1548 .

meltilo: commissioner?

Menancabo: the Minangkabau area in West Sumatra.

Mendonça, Diogo de: Portuguese captain, that served the Estado da Índia in several areas of the Indian Ocean, in the early seventeenth century, always together with his two brothers, Diogo and Álvaro.

meskite / muskita: mosque.

mestilo: see meltilo

mijl: at the beginning of the seventeen century, the length of the Dutch mile was 7,407 meters (http://resources.huygens.knaw.nl/vocglossarium/ vocoutp).

Moluccos / Molucques: the Moluccas archipelago in present Indonesia. This archipelago was well-known as the sole source for clove and nutmeg during the period under review here. The Portuguese settled in Ternate in 1522 , but their influence began to decline in the archipelago a few decades later. The Dutch landed in the Moluccas in 1599. See also Amboin and Bandan.

Moor / Mooren: this word is used with two different meanings in the Dutch sources presented here: firstly "Muslim"; secondly, Muslims from the Coromandel coast, north of Pulicat. In Batavia, even people from the Malabar coast were included under this appellation (Haan 1935: 377). This term had sometimes a wider meaning, that is "Muslim subject of the Mughal emperor" or "Muslim from Ceylon" (Coolhaas (ed.), Generale Missiven, 1971, vol. 4, p. 195, footnote 2).

Mordillion: see Bordolongh.

Muar: river / small town and inner-port near Malacca, also known as Bandar Maharani.

musketier / Musquettier: musketeer. A musket was a firearm, which appeared in Europe in the early 1500s. Fired from Y-shaped supports, it was a shoulder arm. There was no musket-proof armors. Being part of infantry units with pikemen, musketeers had to move in an out of the pike formations to try to get a clear shot at the enemy. Musketeers could be 
recruited from unskilled peasants (Chase 2008: 61-62, 75).

muskita: see meskite.

muscus: musk. Strong-smelling substance secreted by a gland of various animals, especially the civet (Viverra tangalunga and other species) and the musk deer (Moschus moscquiferus), in Southeast Asia, China and Bengal. Musk was traded in two forms at the time under review here, either the complete gland or only the dried content. At the time, used in perfumery in the West (Savary, vol. 3, 1741: 521-523).

nachoda / nachodo / necodá: corrupted form of the Malay nakhoda, shipmaster.

nacie: The original term nacie used in Middle Dutch has no political connotation and refers to an (ethnic) community rather than a country or a state; this meaning has been maintained in modern Afrikaans.

Nagapatam: Nagapattinam. Port of Coromandel where Portuguese traders settled by the mid-1520s, and remained active up to 1658 , when it was conquered and fortified by the VOC. Its traffic with Southeast Asia increased from late sixteenth century and remained stable throughout the following century. The main Southeast Asian ports trading significantly with Nagapattinam were Aceh, Banten, Malacca, Johor, Makassar and Kedah.

nauio de gauea: navio de gávea, that is a ship (usually a carrack with a crow's nest on the top of the tallest mast).

Nunes, Bastião: Portuguese soldier in Asia.

nurimbergher: ware. These are haberdashery and hardware items (Savary, vol. I, 1723: 378, 784, 931, 1097, 1225).

Orancaia / Orankaya / Oran Caya / Orangcaya / Orancaio / Orancayo: "orangkaya" in Malay. The term has been given various definitions. According to Lombard (1967: 56; 1990, II: 144), the orangkaya was a rich individual in the kingdoms of Maritime Southeast Asia during the period fifteenth seventeenth centuries. He occupied a privileged social position, rewarded by the ruler with various, but non-hereditary, civil and military offices. In contact with foreign merchants, he enjoyed a certain prestige among the natives, and generally ruled over a territory outside the capital. They constitute the "aristocracy" of the sultanates and new networks appeared around them: confidants, secretaries, business managers, various agents, henchmen and servants. According to Ito (1984: 81), as the term orangkaya was used to denote rank of dignity rather than title, he suggests to translate it as "The Honourable". Reid (1993, vol. II: 115) distinguishes three types of orangkaya: the foreign merchants, attracted to the port by its trading opportunities, but able to leave again; foreign or foreign-descended, partly assimilated merchant- 
officials, mediating between the court and traders; indigenous aristocrats drawn into trade by their position or wealth. More recently, Guillot (2005: 45) characterises the orangkaya as the "middle class".

Orieda: Ayutthaya. City, capital of the kingdom of Siam between 1350 and 1767.

Ormuz: the city-island of Hormuz, in the Persian Gulf.

Paducca: corrupted form of Paduka in Malay. In Patani, part of the title used by the queen Raja Ungu (Paduka Syah Alam), r. ca. 1629-1634. At the time, the title "Paduka" was also used by a high dignitary of the sultanate (cf. chapter "domestic issues"). The title was in use since the fifteenth century at least in the sultanate of Pasai, especially for women (cf. Guillot $\&$ Kalus 2008). Paduka later became an honorific addition (meaning "royal") in titles.

Pahan / Pasan: Pahang. A river and a sultanate on the east coast of the Malay Peninsula.

pantgypan: shimmering taffeta.

Paribara: probably Patih Barah (?), a Javanese sea-captain and corsair.

Parles: Perlis, a small state vassal of the sultanate of Kedah by this time. Perlis, or Perlis Indera Kayagan, is the smallest state in Malaysia, at the northern tip of the west coast of the Malay Peninsula and has Thailand on its northern border.

Pattas: a type of cloth made of silk and cotton.

Pegu: a Mon port-city in present southern Myanmar/Burma, considered as one of the nodal points of long-distance trade in Southeast Asia from the fifteenth century. Pegu was overrun by the Burmese kingdom of Toungoo in 1539, which established its capital there. Pegu reached its peak around 1570, before to be burnt by armies of formerly loyal territories joined by Ayutthaya's army in 1599. In 1632, a new capital was established by the Toungoo dynasty far inland, in Ava.

Phaon: see Pahang.

picol / picoll: corrupted form of the Malay pikul. Unit of weight, equal to 100 katis, or two bags of 60 pounds, that is approximately $60 \mathrm{~kg}$.

pieckenier: pikemen. Pikemen were a component of infantry units together with musketeers. The pike was basically a long spear, about 4.5 metres in length, matchless as part of a solid mass of unbroken infantry presenting a continuous front to the ennemy (Chase 2008: 62).

pinas / pinasse: pinnace. A general name for single-decked, square-sterned vessels used for exploration and trade.

pissan: corrupted form of the Malay pisang, that is banana (Musa paradisiaca). 
pongoulu / pongulo: corrupted form for the Malay penghulu, headman.

Portingalls: Portuguese people.

Pratiau: corrupted form for the Thai Phra-cao, a royal title used to designate most of the queens of Patani (Teeuw \& Wyatt eds., 1970, vol. I: 13; vol. II: 230).

prau / prauw / prauwe: Proa. Corrupted form for the Malay perahu. Small native sailing vessel.

proa: see prau.

Pulo Timão: Pulau Tioman, island off Pahang on the east coast of the Malay Peninsula.

puntu gorbangh: corrupted form of the Malay pintu gerbang, main gate.

pynangdoos: combination of the Malay pinang with the Dutch doos for a box containing all appliances connected with the chewing of the areca-nut.

Quala Buca / Quale Bouca: corrupted form of the toponym Kuala Bekah in Malay. cf. chapter "domestic issues".

Queda: see Keda.

quelyns: refers to the Kelings or Klings, Tamil merchants from the Coromandel Coast.

radix china: dried root of a thorny vine (Smilax China Linn.), originally growing in China and Japan. Used in Europe from the sixteenth century to treat various diseases, especially syphilitic ailments (Orta 2004: 525-541).

Radza Muda: corrupted form of Raja Muda in Malay, meaning "heir to the throne". See chapter "domestic issues".

Radzia Calanta: corrupted form of Raja Kelantan in Malay. cf. chapter "domestic issues".

Raga Wange: cf. chapter "domestic issues".

Ragia Siacq: corrupted form of Raja Siak in Malay, meaning "king of Siak". See Siacq.

Rahu Bongso, Raja Bonso: corrupted form of Ratu Bongsu in Malay. Also know as Raja Bongsu, Raja Seberang or Raja di Ilir. Brother of the Sultan of Johor, Ala'uddin Ri'ayat Syah III, he succeded him with the title of Sultan Abdullah Ma'ayat Syah in 1613 at Makam Tauhid / Batu Sawar (near present Kota Tinggi), before to leave for Pulau Bintan in 1617 and then Pulau Lingga in 1618 where his reign ended in 1623.

Raia Indra Mouda: corrupted form of Raja Indra Muda in Malay.

Raja Sitterbangsa: corrupted form of Raja Setiawangsa in Malay.

Raja Schey: perhaps corrupted form of Raja Shaikh in Malay.

Raposo, Baltasar Rodrigues: a Portuguese ship captain, born in the Alentejo 
province, in the south of Portugal.

rial van acht: real van acht, piece-of-eight. Spanish-American silver coin (peso) issued since about the middle of the sixteenth century and widely accepted in Southeast Asia. Its value, eight reales, is frequently found on the side of the armorial shield on the reverse (VIII or 8), hence the expression "piece-of-eight".

roode steen / red stones: bricks.

roosenobel: gold coin issued in the Low Countries being a close imitation of an English gold coin first issued in 1344, during the reign of Edward III. The prominent feature of the coin is the ship in which stands the king holding a sword and shield (Frey 1916: 160).

sabandaer / sabander: corrupted form of the Malay syahbandar. Head of the port, in charge of foreigners.

Sabbath: word used by Roelof Roelofsz to mean "Friday". Indeed, November 9, 1601, fell on Friday, 13 Jamadilawal $1010 \mathrm{H}$.

Sabrang / Sabrangh / Sabraugh: corrupted form of the Malay "Seberang". Here it means the peninsula closing the Patani Bay.

sagou / Sagu: sago (Metroxylon spp.). Genus of palms. The soft inner parts of the trunk contain edible starch after washing.

salala: probably corrupted form of the Malay serasah. A linen or cotton printfabric obtained from the Coromandel coast (Wilkinson 1959, vol. II: 1082).

Sangora / Songora / Singgora: modern Songkhla, a coastal town northwest of Patani. A major port through the seventeenth century. Some pepper was also cultivated there until the end of the seventeenth century. Conflicts were frequent between Patani and Singgora between the mid-1620s and the mid-1630s. The VOC had a factory there between 1613 and 1618.

saroy boura: corrupted form of sarang burung (bird's nest) in Malay. Edible nests produced by the glutinous saliva of swiftlets and harvested from caves throughout Maritime Southeast Asia.

scharlaken: scarlet. Fine woollen cloth.

schuyt: schuit. Small boat, generally for inland navigation.

Seeram: Seram. The largest and main island of the Moluccas archipelago.

saluajes: selvagem, a large piece of artillery, weighing some 2,800 kilograms, and firing balls of 16 pounds.

Seelant: see Zeeland.

Siacq: Siak. River and polity on the east coast of Sumatra. Among the trade entrepots for products from the Minangkabau highlands. Siak was more or less controlled by Malacca in the second half of the fifteenth century, and then by Johor after 1511. The conquest of Malacca by a Dutch-Johor 
force in 1641 gave the opportunity to Johor to reaffirm its authority over Siak.

Sineau: probably a corruption of Chinceo. See Chinceo.

Sirindana: cf. chapter "domestic issues".

Siriniara / Siriuara / Sirnora: probably the title 'Seri Nara'. cf. chapter "domestic issues".

sloep: sloop, single-masted vessel.

Solnara: see Siriniara.

Solor: a volcanic island, off the island of Flores in the Lesser Sunda Islands, Solor Archipelago.

sombah benaga: corrupted form of the Malay "sembah berniaga". Trade fee. Literally "gesture of homage to thank for the right to trade".

sombah datang: corrupted form of the Malay "sembah datang". Arrival fee.

sombah datching: corrupted form of the Malay "sembah dacing". Weighing fee.

sombah muson: perhaps corrupted form of the Malay "sembah musim". Seasonal fee (?). Perhaps related to the fact that the coming of trading ships depended on seasonal winds.

Soutra touloucky: perhaps corrupted form of the Malay "sutera tolok (?)". See damast.

stuyver: copper coin of the Low Countries and various German States, dating from the middle of the sixteenth century. There is an extensive series of stuivers issued by the Dutch for their possessions in the East, struck in copper, lead and silver (Frey 1916: 230).

Succadama / Suckidana: Sukadana. Diamond-producing polity in southwest Borneo. The Dutch established a factory there in 1608.

Sunda: the kingdom and port-city of Sunda Kelapa in West Java.

Syam: Siam.

taffeta: a fine smooth Chinese silken stuff, remarkable for its gloss or lustre.

Tanjampura: the port and kingdom of Tanjung Pura, on the island of Borneo.

Tanasserin: Tenasserim. The southernmost province of modern Myanmar. Tenasserim and the port of the same name were conquered by Siam under King Naresuan (1590-1605), then taken by the Burmese after the fall of Ayutthaya in 1767.

Tanjongh Selang: Tanjong Selang, also Ujung Selang. Present Phuket on the west coast of Peninsular Thailand.

Tarangh: see Trang. 
Ternate: the island and sultanate of Ternate, in the Halmahera group of North Maluku, a source and market for cloves.

Tidore: the island and sultanate of Tidore, in North Maluku, a fierce rival of Ternate.

Timor: an island at the southern end of Maritime Southeast Asia, long known for its sandalwood.

tintenage: tutenague. Alloy of copper, zinc and nickel exported from China.

Trang: Trang. River-port town on the Andaman Sea coast of Siam, southeast of Phuket.

tschera Malleyas: a type of "Malay" cloth of silk.

tsulia: type of cloth.

tutuão: dutang, or Executive Censor, a Chinese official of the Ming dynasty.

Ujantana /Viantana: see Johor

valcoen / falcones: falcon. Small caliber cannon firing balls weighing between a quarter of a pound and a half pound.

Vasconcelos, Henrique Mendes de: a Portuguese ship captain, that served the Estado da India as captain of the Banda Islands around 1536.

versos / bersos: berços, a small piece or artillery firing ball of three pounds. was / waxe: bees wax.

Zangora: see Sangora.

Zeeland: the westernmost province of the present Netherlands. When mentionned in the sources presented here, in the first decade of the seventeenth century, Zeeland was part of the Dutch Republic established in 1588, a federation of seven autonomous provinces. Spain formally recognized the Republic in 1648.

Zeylon: Ceylon. 
